\title{
Board diversity and firm performance: cases in sharia capital market of Indonesia
}

\author{
Sutrisnoํㅜ, Maslinawati Mohamad² \\ ${ }^{1}$ Universitas Islam Indonesia, Yogyakarta, Indonesia \\ ${ }^{2}$ Universiti Teknologi MARA, Selangor, Malaysia \\ *Corresponding author: sutrisno@uii.ac.id
}

\begin{abstract}
The purpose of this study is to examine the effect of board diversity on corporate performance. In this paper, board diversity refers to the composition of board members consisting of women, foreign, ethnicity, size of the board of commissioner, and size board of directors. Whereas, corporate performance is measured by return on assets (ROA). The sample size of the study uses 48 publicly listed firms in the Sharia capital market of Indonesia for the observation period between 2015 and 2017. The results show that firms with women and foreigner in board had a significant and positive association with corporate performance. Similarly, the board of commissioners and the board of directors also had a significant and positive association with firm performance. However, the existence of the ethnic boards does not affect firm performance.
\end{abstract}

Keyword: board diversity, board of women, board of foreign, board of ethnic, corporate performance. JEL Classification Code: D21, D22, D24 DOI: 10.20885/jsb.vol23.iss2.art1

\section{Introduction}

The role of board diversity on firm performance has been widely investigated (see e.g. Endraswati (2018), Hidayat and Utama (2016), Vafaei et al. (2015), Abdullah and Ismail (2013), Darmadi (2011), Ararat et al. (2010), Choi and Hasan (2005), and Marimuthu (2008)). In this study, board diversity refers to the composition of board member which consists of gender, foreigner, and ethnicity. The results of studies document that the association between board of diversity and firm performance is mixed. This study investigate the impact of board diversity and size of board on firm performance by focusing on firms listed on Sharia capital market of Indonesia.

The existence of foreign director in the board of directors and board of commissioners is often considered to be effective to control activities in terms of carrying out the firm operations. Ararat et al. (2010) argued that foreign members bring in diverse opinions and perspectives in terms of education, experience, work culture and professionalism. Shleifer and Vishny (1986) stated that foreign shareholders who have a large percentage of ownership can carry out active supervision through foreign board members. Choi and Hassan (2005) found that foreign boards have a positive impact on company's performance, suggesting that the existence of foreign boards is able to improve company performance. Ararat et al. (2010) find that nationality has a positive effect on firm performance, suggesting that the existence of a foreign director on board members is able to invite foreign investors to invest in the company. On the other hand, Darmadi (2011) find there is no significant influence between different nationalities and firm performance.

Besides foreign boards is perceived as a variable to improve performance, several companies assign women in board. The existence of women as board member is expected to prevent conflicts among board members. Women on boards have an important role in the proses of decision making. The involvement of women provides the balance in terms of the decreasing of the domination of male in firms decision. Abdullah and Ismail (2013) found there is a significant and positive effect between the existence of women in board and firm financial performance. Sarkar and Selarka (2015) and Julizaerma and Sori (2012) also found that the existence of women's boards improved financial performance. However, different results are found by Endraswari (2018) in Indonesia, Carter et al. 
(2010) in America and, Agyapong and Apiah (2015) in Ghana that the existence of women in board does not have impact on firm performance.

The existence of certain ethnic boards can also encourage better company performance, especially in Indonesia where almost all companies are led by those of Chinese ethnicity. Abdullah and Ismail (2013) find there is a positive association between ethnic diversity and firm performance. They also find that a board consisting of representatives from three main ethnic groups performs better than that of consisting one or two ethnic groups. However, Carter et al (2010), Hassan et al. (2017) and Marimuthu (2008) find that there is insignificant effect between the existence of ethnic boards and company performance.

Some studies document the impact of size of board of commissioners and board of director on firm performance. The board of commissioners have control mechanism which is collectively responsible for supervising and giving input to the board of directors and ensuring that the company properly implements good corporate governance. The position of the board of commissioners is very important in terms of bridging the interests of the principal in a company. The large number of commissioners allows the board to make decision and to conduct advocacy effectively. As argued by Susanti and Nidar (2016) and Siahaan (2013), the board of commissioners can improve firm performance. Similarly, Ararat et al. (2010) and Hidayat and Utama (2016) find the same results. However, the findings of Gill and Obradovich (2012) show that the number of board of commissioners has a negative effect on company performance.

The board of directors is an agent that execute the firm operations (Susanti and Nidar, 2016). The board of directors has responsibility to establish strategic direction, to manage operational policies, and to ensure the level of financial health of company. Each member of the board of directors can carry out their respective duties and make decisions in accordance with the division of duties and authority. Studies by Susanti and Nidar (2016), Hidayat and Utama (2016), Siahaan (2013), Makhlouf and Al-Sufy (2018) and Ararat et al (2010) find that there is a positive and significant association between the size of board of directors and firm performance. On the other hand, the studies by Gill and Obradovich (2012) and Darmadi (2011) find that the number of director on the board does not have affect on company performance.

\section{Literature Review}

\section{Board of Women and Corporate Performance}

One of the manifestation of diversity on the board is by assigning women on board. Their existence shows that the company does not have a discriminative policy by providing equal opportunities for everyone. The characteristics of women may refer to their behavior in some aspects such as careful decision making and more risk averse compared to men. Their existence is also expected to be able to reveal more information to the shareholders (Abdullah and Ismail, 2013). Compared to men who have greater motivation in terms of the achievements in the material domain, women may have more opportunistic actions. Carter et al. (2010) argues that the existence of women in the company's board is an honor because they consider that it is difficult to obtain the post. Sarkar and Selarka (2015) and Julizaerma and Sori (2012) find that the existence of women in board has a positive and significant effect on corporate performance.

$\mathrm{H}_{1}$ : Board of women have a positive effect on corporate performance

\section{Foreign Boards and Corporate Performance}

The existence of a foreign board can be determined from the organizational structure of the company, namely by looking at the profile of the board of commissioners or directors. Foreign boards serve as an external pressure to introduce corporate governance practices that are widely considered. Shleifer and Vishny (1986) argue that foreign shareholders who have a large percentage of the total ownership can carry out active supervision through foreign board members. According to Ararat et al. (2010), 
the existence of a foreign board can bring in new opinions and professional perspective to the company. Choi and Hassan (2005) found that foreign boards have a positive impact on performance. Ararat et al. (2010) found that foreign boards had a positive effect on the performance of companies in Turkey. This is because the existence of a foreign board was able to invite foreign investors to invest in the Turkish companies. Meanwhile, Darmadi (2011) found there to be no influence from foreign boards on company performance. The research results of Oxelheim and Randoy (2003) show that foreign boards are able to increase the value of the company. Similarly, Bremholm (2015) also found there to have been the same effect.

$\mathrm{H}_{2}$ : Foreign boards have a positive effect on corporate performance

\section{Ethnic Board and Corporate Performance}

In terms of the composition of the Indonesian population, one of the ethnicities that makes up the population is Chinese. The Chinese ethnicity is an minority ethnic group in Indonesia but it has a significant influence in the business world (Kusumastuti et al., 2007). The Chinese ethnicity is very heavily associated with Confucian culture. The Confucian teachings include Love (Ren), Truth (Yi), Decency (Li), Wisdom (Zhi), Trustworthiness (Xin), Courage (Yong), Change (Yin Yang) and Networking / Relationships (Guanxi). Many Chinese people apply Confucius' teachings in their business. By applying the teachings in business (entrepreneurship), it encourages the emergence of business capabilities so then the betterment of the company performance can be achieved (Sularso, 2013). Danes et al (2008) believes that the existence of ethnic boards will make the company more advanced because in general, ethnic boards have a high entrepreneurial spirit. Abullah and Ismail (2013) found there to be a positive influence between ethnic boards and company performance.

$\mathrm{H}_{3}$ : Ethnic boards have a positive effect on corporate performance

\section{Board of Commissioners and Corporate Performance}

The board of commissioner as a corporate organ has the duty and responsibility collectively to supervise directors and to ensure that the company implements GCG. However, the board of commissioners may not participate in making operational decisions. To keep the board of commissioners working in accordance with their authority, independent commissioner members are needed. A number of commissioners may be effective to oversee directors. The number on the board of commissioners varies between companies; the more members of commissioners, the more effective it is in the supervision. However, this does not mean that the larger the size of commissioners, the higher the firm performance. Inded, their correlation might be non linear. Susanti and Nidar (2016) and Siahaan (2013) find there is a positive and significant association between the board of commissioners and company performance. Ararat et al. (2010) and Hidayat and Utama (2016) also found the same effect.

$\mathrm{H}_{4}$ : The size of board of commissioners has a positive effect on corporate performance

\section{Board of Directors and Corporate Performance}

Board of directors has very important role in a firm. The separation of the role between board of commissioners and board of directors means that the board of directors have great power in terms of managing all of the available resources within the company. The board of directors have responsibility to determine the the policies and strategies regarding the resources possessed by the company. As it is explained by the Company Law that the board of directors has the right to represent the company's interest either outside or inside of the firm. The number of directors will logically affect the speed of corporate decision making. With the existence of several members of the board of directors, good coordination between members of the board of directors and the board of commissioners is needed. Makhlouf and Al-Sufy (2018) and Ararat et al. (2010) find there is a positive and significant 
association between te size of board of directors on firm performance. Similar findings are also found by Susanti and Nidar (2016), Hidayat and Utama (2016) and Siahaan (2013).

$\mathrm{H}_{5}$ : The size of board of directors has a positive effect on corporate performance

Based on the background, in addition to the study of the theories and hypotheses described above, the research framework can be detailed as follows.

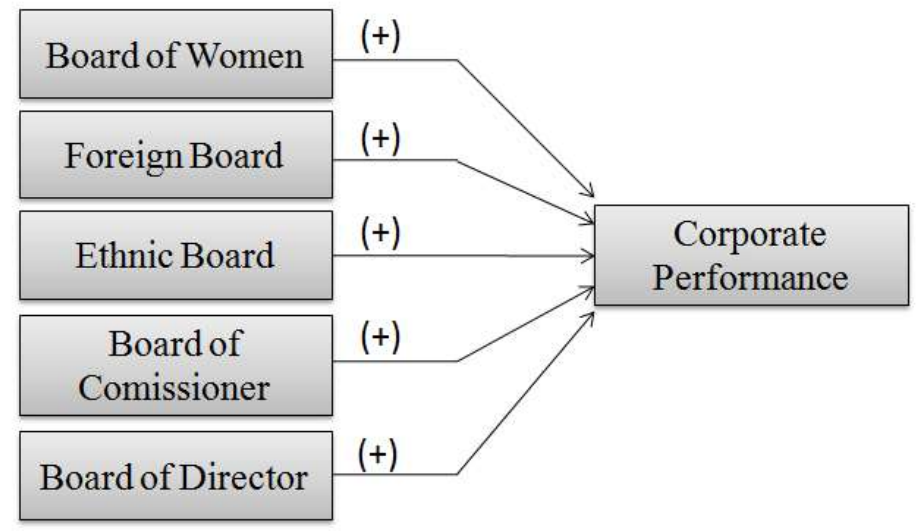

Figure 1. Research Framework

\section{Methods}

\section{Population and Sample}

The population in this research consisted of firms listed in in the Syaria capital market of Inonesia with a total sample of 48 firms which is chosen by using a purposive sampling method. The observation period was three years (2015 - 2017).

\section{Research Variable}

In this research, we use one dependent variable, corporate performance, which is measured by return on assets (ROA), and five independent variables consisting of the women in board, foreign in board, ethnicity in board, the number of member of board of commissioners, and the number of board of directors. The measurement of each variable is as follows:

Table 1. Variables and Measurement

\begin{tabular}{lll}
\hline \multicolumn{1}{c}{ Variable } & \multicolumn{1}{c}{ Symbol } & \multicolumn{1}{c}{ Measurement } \\
\hline Corporate Performnace & ROA & Earnings after tax/ Total Assets. \\
Women in board & B_WOM & Dummy variable: 1 if there is, and 0 otherwise. \\
Foreign in board & B_FOR & Dummy variable: 1 if there is, and 0 otherwise. \\
Ethnicity in board & B_ETH & Dummy variable: 1 if there is, and 0 otherwise. \\
Board of commissioner & B_COM & Number of member of board of commissioner \\
Board of director & B_DIR & Number of member of board of director. \\
\hline
\end{tabular}

Data Analysis

To test the hypotheses, multiple regression analysis is used with a significance level of 0.05 . The following is the model of regression equation:

$$
\mathrm{ROA}=\alpha+\beta_{1} \mathrm{~B} \_\mathrm{WOM}+\beta_{2} \mathrm{~B} \_\mathrm{FOR}+\beta_{3} \mathrm{~B} \_\mathrm{ETH}+\beta_{4} \mathrm{~B} \_\mathrm{COM}+\beta_{5} \mathrm{~B} \_\mathrm{DIR}+\varepsilon
$$




\section{Results and Discussion}

Before testing the hypotheses, classical assumption tests were carried out. The results showed that the results of multicollinearity test, the autocorrelation test and the heteroscedasticity test do not violate the classical assumption test. Next, the hypotheses are tested by using multiple regression.The table below shows the results of the data processing using multiple linear regression analysis.

Table 2. Hypothesis Test Result

\begin{tabular}{|c|c|c|c|c|c|c|}
\hline \multirow{2}{*}{\multicolumn{2}{|c|}{ Model }} & \multicolumn{2}{|c|}{$\begin{array}{l}\text { Unstandardized } \\
\text { Coefficients }\end{array}$} & \multirow{2}{*}{$\begin{array}{c}\text { Standardized } \\
\text { Coefficients } \\
\text { Beta } \\
\end{array}$} & \multirow[t]{2}{*}{$\mathrm{t}$} & \multirow[t]{2}{*}{ Sig. } \\
\hline & & $\mathrm{B}$ & Std. Error & & & \\
\hline \multirow{6}{*}{1} & (Constant) &,- 055 & ,016 & & $-3,332$ & ,001 \\
\hline & B_WOM & ,027 & ,012 & , 192 & 2,366 & 019 \\
\hline & B_FOR & ,028 & 011 & 201 & 2,523 & 013 \\
\hline & B_ETH & -.020 & .025 & -.105 & -.785 & .436 \\
\hline & B_COM & ,008 & ,004 & ,182 & 2,200 & ,029 \\
\hline & $\begin{array}{l}\text { B_DIR } \\
\text { endent Vari }\end{array}$ & ,007 & ,003 & , 185 & 2,250 & ,026 \\
\hline
\end{tabular}

Based on the results of the Table 2, the results indicate that the existence of a female in board (B_WOM) has a significant and positive effect on corporate performance. The existence of women on the board is needed because of the nature of women. They are very patient and conscientious when they make firm decisions. Their use of caution and tendency to avoid risks will influence the decisions taken by the board (Abdullah and Ismail, 2013). These findings are in accordance with the research by Sarkar and Selarka (2015) and Julizaerma and Sori (2012), who find there is a significant and positive influence between women in boards and firm performance. However some researchers found that women in boards does not have effect on firm performance (Endraswari, 2018), (Carter et al, 2010) and (Agyapong and Apiah, 2015).

Foreign boards (B_FOR) have a positive and significant effect on corporate performance. The use of foreigners to occupy the position is intended to build the image of firm and to have work professionally in regard of international relations. This may have positive impact not only on global relation, but also on firm competitiveness. As it is found by Oxelheim and Randoy (2003), foreign boards are able to increase company value. Similarly, Bremholm (2015) also found there is a significant association between the existence of foreigner in board and firm performance.

Table 2 also shows that the Ethnicity in Board does not have significant influence on corporate performance. The ethnic boards that exist in companies in Indonesia are mostly Chinese ethnic as a large number of companies in Indonesia are owned by Chinese ancestors. In addition, almost all companies listed on the Indonesia Stock Exchange have board members of Chinese ethnic. In general, Chinese ethnic in board have a high work ethic and high spirit which can be adopted by the other board members. These results support the study by Charter et al. (2010) who found there is no association between ethnicity in boards and firm company performance. Other studies by Marimuthu et al. (2009) and Hasan et al. (2017) also found the similar results.

The board of commissioners (B_COM) has a positive association with corporate performance, suggesting that the more staff member of commissioners, the better firm performance. The board of commissioners has the duty of overseeing and controlling the board of directors. In addition, board of commissioners can direct the work of board of director to work in accordance with the objectives set by general meeting of shareholders. This study suggests that a large number of boards of commissioners make more effective supervision. These results support the study by Susanti and Nidar (2016), and Siahaan (2013) who find that there is a positive and significant association between the number of board of commissioners and firm performance. Similarly, Ararat et a.l (2010) and Hidayat and Utama (2016) find the same conclusion. 
The board of directors (B_DIR), measured by the number of boards of directors, also has a positive and significant effect on corporate performance. The board of directors is a trusted agent that have responsibility to manage the company's assets and human resources. In addition, the board of directors has the right to represent the company in various activities. The number of board of directors will influence the speed and power of the firm decision making. This results suggests that the firm performance is highly depend on the quantity of the member on board of directors as their duties to make the firm continuously grows. The study by Makhlouf and Al-Sufy (2018), and Ararat et al. (2010) show that there is a positive and significant association between the number of boards of directors and firm performance. The study by Susanti and Nidar (2016), Hidayat and Utama (2016) and Siahaan (2013) find that the board of directors has positive and significant influence on firm performance.

\section{Conclusion}

Based on the results of the hypothesis testing, it can be concluded that the existence of women and foreigner in boards have a significant and positive effect on firm performance. This result is in accordance with the findings of Abdullah and Ismail (2013), Carter et al. (2010) and Bremholm (2015). The existence of ethnic boards, on the other hand, does not have effect on firm performance. This result may be explained by the fact that the majority of sample companies assign Chinese ethnic on the board. The number of member of board of directors and board of commissioners have a significant and positive effect on firm performance. Regarding this findings, this study is consistent with the results of research by Susanti and Nidar (2016), Hidayat and Utama (2016) and Ararat et al. (2010). The study suggest that the number of board of commissioners and directors needs to be added if the firm performance has not optimal, but it must consider the excess of board members. In addition, the study suggests to consider the assigning of women and foreigner on board members.

\section{Acknowledgement}

The researcher would like to express his utmost gratitude to the Center for Management Development (PPM), the Department of Management, Faculty of Economics, Universitas Islam Indonesia, who provided funding for this research and conference.

\section{References}

Abdullah, S.N dan Ismail K.N.I.K. 2013. Gender, Ethnic and Age Diversity of the Boards of Large Malaysian Firms and Performance. Jurnal Pengurusan 38(2013) 27 - 40

Agyapong, D and Appiah, S.O. 2015. Effect of Gender Diversity on the Performance of Non-financial Listed Firms in Ghana. British Journal of Economics, Management \& Trade. Vol 8(1). 55-67

Ararat, M., Aksu, M., and Cetin, A.T. 2010. Impact of board diversity on board's monitoring intensity and firm performance: Evidence from the Istanbul Stock Exchange. Proceeding: 17th Annual Conference of the Multinational Finance Society. Barcelona.

Bremholm, A. 2015. Foreign ownership and foreign directors-the effects on firm performance in Japan. Working Paper. Lund University.

Carter D.A., D’Souza F., Simkins B.J. and Simpson W.G. 2010. The Gender and Ethnic Diversity of US Boards and Board Committees and Firm Financial Performance. Corporate Governance: An International Review. Vol 18(5). 396-414

Choi, S, and Hasan, I. 2005. Ownership, Governance, and Bank Performance: Korean Experience. Financial Markets, Institutions \& Instruments. Vol. 14, No. 4, pp 215-242 
Danes S.M., Stafford K and Heck R.K.Z. 2008. The Effects of Ethnicity, Families And Culture On Entrepreneurial Experience: An Extension Of Sustainable Family Business Theory. Journal of Developmental Entrepreneurship Vol. 13 (3). 229-268

Darmadi, S. 2011. Board Diversity and Firm Performance: The Indonesian Evidence. MPRA Paper. No.38721, http://mpra.ub.unimuenchen.de/38721

Endraswati, H. 2018. Gender Diversity in Board of Directors and Firm Performance: A Study in Indonesia Sharia Banks. Review of Integrative Business and Economics Research, Vol. 7(1). 299-311

Gill A and Obradovich J. 2012. The Impact of Corporate Governance and Financial Leverage on the Value of American Firms. International Research Journal of Finance and Economics. Vol. 91. $1-15$

Hassan, R., Marimuth, M., Tariq, E and Aqeel, R. 2017. Ethnic and Gender Diversity in Top Level Management and Firm Performance: Shareholder's Perspectives. Journal of International Women's Studies Vol. 18(4). 1-12

Hidayat, A.A. and Utama, S. 2016. Board Characteristics and Firm Performance: Evidence from Indonesia. International Research Journal of Business Studies. Vol. 8(3). 137-154

Julizaerma, M.K and Sori, Z.M. 2012. Gender Diversity in the Boardroom and Firm Performance of Malaysian Public Listed Companies. Procedia - Social and Behavioral Sciences. Vol 65. 1077 $-1085$

Kusumastuti, S., Supatmi and Sastra, P. 2007. Pengaruh Board Diversity terhadap Nilai Perusahaan dalam Perspektif Corporate Goovernance (The Effect of Board Diversity on Firm Value in Cosporate Governance Perspectives). Jurnal Akuntansi dan Keuangan. Vol 9, No.2. hal 8898.

Makhlouf, M.M. and Al-Sufy, F. 2018. Board of Directors, Firm Performance and The Moderating Role of Family Control in Jordan. Academy of Accounting and Financial Studies Journal. Vol 22(5). 2-15

Marimuthu M. 2008. Ethnic Diversity on Boards of Directors and Its Implications on Firm Financial Performance. The Journal of International Social Research Volume 1(4). 431-446

Marimuthu, M. Rahman, T.A, and Kolandaisamy, I,. 2009. Ethnic and Gender Diversity in Boards of Directors and Their Relevance to Financial Performance of Malaysian Companies. Journal of Sustainable Development. Vol 2(3). 139-148

Oxelheim, L and Randoy, T. 2003. The impact of foreign board membership on firm value. Journal of Banking \& Finance. Vol 27. 2369-2392

Sarkar, J and and Selarka, E. 2015. Women on Board and Performance of Family Firms: Evidence from India. Working Paper. Indira Gandhi Institute of Development Research, Mumbai

Shleifer, A. dan R. Vishny. 1986. Large Shareholders and Corporate Control. Journal of Political Economy. Vol. 94, (3). 461-488

Shleifer, A. dan R. Vishny. 1997. A survey of corporate governance. Journal of Finance. Vol. 52. 737783

Siahaan, F. 2013. The Effect of Good Corporate Governance Mechanism, Leverage, and Firm Size on Firm Value. GSTF Journal on Business Review. Vol.2(4). 137-142

Sularso, A.R. 2013. Effect of Ethics Confucius, Entrepreneurship, Customer Satisfaction And Business Skills Perceived Image On Business Performance. Jurnal ISEI Jember. Vol, 3(1). 101 - 109 
Susanti, L and Nidar, S.R. 2016. Corporate Board And Firm Value: Perspective Two-Tier Board System In Indonesia. International Journal of Scientific \& Technology Research. Vol 5(5). 300305

Vafaei A., Ahmed K. and Mather P. 2015. Board Diversity and Financial Performance in the Top 500 Australian Firms. Australian Accounting Review No. 75. Vol. 25(4). 413-428 